\title{
Specifické otázky implementace intervenčních programů pro podporu rozvoje pregramotnostních dovedností ${ }^{1}$
}

\author{
Petra Šedinová, Gabriela Seidlová Málková
}

\begin{abstract}
Abstrakt: Tato studie shrnuje poznatky z výzkumu intervenčních programù cílených na rozvoj pregramotnostnich dovednosti (fonematického uvédomováni a znalosti pismen) dèti v predškolnim věku a to s dirazem na popis rüzných forem realizace a implementace téchto programü. Představujeme koncepčni a teoretická východiska pro tvorbu pregramotnostně orientovaných programu a následně demonstrujeme variabilitu forem, v jakých jsou tyto programy konstruovány pro užití $v$ praxi a implementovány pro potreby zvolených cílových skupin. Otázkám implementace věnujeme zvláštni pozornost, jelikož predstavuji cenné opory pro prípadné zhodnoceni $v$ kontextu pedagogicko-psychologické a speciálně pedagogické praxe. Zvláśt prezentujeme prehled poznatkư z mezinárodního výzkumu a z výzkumu v českém a slovenském prostredí. Vnávaznosti na analýzu stávajiciho rozsahu poznatků a zkušeností z výzkumu v domácím kontextu také prezentujeme podobu nově vznikajicího metodického materiálu pro práci poradenských pracovnikü, prípadně pedagogů v mateřských školách.
\end{abstract}

Klícová slova: alfabetický princip, intervenčni programy, fonematické uvédomování, znalost pismen, predškolni věk

\section{Potřeba INTERVENČNích}

STUDIÍ VE VÝZKUMU VÝVOJE

GRAMOTNOSTI A PREGRAMOT-

NOSTNÍCH DOVEDNOSTÍ

Klíčový význam jazykových, kognitivních a ortografických schopností pro rozvoj raných i počátečních čtenářských dovedností, včetně čtení s porozuměním, dokládá řada odborných studií dostupných v současné odborné literatuře (např. Caravolas et al., 2012, 2019; Moll et al., 2014; Kirby et al., 2010; Verhoeven \& Van Leeuwe, 2008). Se zahájením formální výuky čtení jsou děti s dobrou

\footnotetext{
${ }^{1}$ Tato publikace vznikla $\mathrm{v}$ rámci řešení projektu GA UK č. 1071716 Systematická intervence v oblasti podpory rozvoje predpokladĩ počátečního čtení a psani řešeného na Pedagogické fakultě Univerzity Karlovy. Práce Gabriely Seidlové Málkové byla také částečně podporována z prostředků Institucionální podpory FHS UK na dlouhodobý koncepční rozvoj výzkumné organizace (MŠMT-2020).
} 
výbavou v oblasti tzv. fonologických schopností a procesů a raných ortografických znalostí ve výhodě oproti dětem vykazujícím v těchto oblastech opožděný vývoj nebo deficity (Markussen-Brown et al., 2017). Výukové a intervenční programy pro podporu rozvoje tzv. pregramotnostních dovedností (zejména tzv. fonematického uvědomování a znalosti písmen) jsou navíc př́nosné nejen pro děti $s$ různým charakterem a závažností obtíží, ale i pro typicky se vyvíjející děti bez obtíží. Řada studií dokládajících prínosy intervenčních programů pro podporu vývoje pregramotnostních dovedností upozorňuje nejen na bezprostřední pozitivní vlivy takových aktivit, ale i na vlivy působící po několik následujících let, resp. v následujících letech školní docházky (Troia, 1999; Bus \& Van Ijzendoorn, 1999; Suggate, 2016).

Včasné poskytování intervenční podpory fonologických a případně i dalších pregramotnostních dovedností v předškolním období se stává důležitým tématem profesní př́pravy učitelů (Markussen-Brown et al., 2017). Vytváření a prověrování efektivity takových výukových aktivit a programů má proto v evropském i mezinárodním výzkumu své pevné místo (Suggate 2016, Bus \& Van Ijzendoorn 1999). V posledních letech také stoupá zájem o testování různých doposud méně obvyklých forem stimulace pregramotnostních dovedností př́edškolních dětí. Nejčastěji jde o různé počítačem asistované postupy nebo programy, výukové a intervenční aplikace, které mohou výrazně pomáhat i aktivnímu zapojování rodičů do práce s dítětem (Segers \& Verhoeven, 2004; Elbaum et al., 2000).

$\mathrm{V}$ této studii se snažíme akcentovat bohatost forem realizace a implementace intervenčních či výukových programů pro rozvoj počáteční gramotnosti (či pregramotnostních dovedností) a upozornit na bohatost poznatků, které jsou v této odborné oblasti $\mathrm{k}$ dispozici. Domníváme se, že množství a pestrost poznatků z této oblasti výzkumu (zejména výzkumu ze zahraničí, částečně ale už i z výzkumu v českém prostředí) představuje nedoceněný potenciál pro zhodnocení v české pedagogicko-psychologické a speciálněpedagogické praxi a poradenství. Naším záměrem je proto poskytnout čtenáři přehled výzkumných studií z oblasti výzkumu intervenčních, na pregramotnost zaměřených programů, a to $s$ cílem akcentovat formy a způsoby jejich realizace či implementace v praxi. Představujeme proto nejprve základní - v současné odborné literatuře sdílená - koncepční a teoretická východiska pro konstrukci těchto programů a následně v návaznosti na objasnění těchto obsahových východisek demonstrujeme variabilitu forem, $\mathrm{v}$ jakých jsou tyto programy konstruovány pro užití v praxi a implementovány pro potřeby cílové populace. Specifikám zavádění a realizace těchto programů $\mathrm{v}$ praxi se věnujeme konkrétněji, vzhledem $\mathrm{k}$ jejich zhodnocení v kontextu pedagogicko-psychologické a speciálněpedagogické praxe. $\mathrm{V}$ závěrečných částech textu představujeme - v návaznosti na stávají- 
cí rozsah poznatků z výzkumu v českém prostředí - nově vznikající metodický materiál (výukový program) určený pro práci poradenských pracovníků, př́ípadně pedagogů a asistentů pedagogů v mateřských školách.

\section{TEORETICKÁ VÝCHODISKA}

INTERVENČNÍCH STUDIÍ

\section{PRO PODPORU ROZVOJE}

\section{PREGRAMOTNOSTI A POČÁTEČNí}

\section{GRAMOTNOSTI}

Výzkumné studie realizované $\mathrm{v}$ různých evropských jazycích v tzv. kroslingvistické perspektivě ukazují, že čtení (i psaní) se rozvíjí na podkladě vývojové interakce klíčových kognitivních, jazykových a ortografických schopností či dovedností a že tempo vývoje počátečního čtení je výrazně ovlivňováno povahou pravopisného systému, ve kterém je čtení osvojováno (Caravolas et al, 2012, 2013, 2019). Caravolasová a kolegové (tamtéž) zjistili ve výzkumu ve čtyřech evropských jazycích (včetně češtiny) $s$ dětmi předškolního a raně školního věku, že variabilitu vývoje počátečního čtení (i psaní) zásadním způsobem ovlivňují tř́i dovednosti či schopnosti: fonematické uvědomování, znalost písmen abecedy a rychlé automatizované jmenování ( $v$ české literatuře označované zkratkou RAN). V rámci longitudinální studie $s$ běžně se vyvíjejícími dětmi (v českém prostředí dokonce $s$ dětmi bez odkladu školní docházky) sestavili predikční modely vývoje počátečního čtení relevantní pro děti od posledního ročníku mateřské školy (cca pět až šest let) až do konce prvního ročníku základní školy (Caravolas et al., 2012). Klíčový vliv uvedených dovedností na kvalitu i variabilitu čtenářských dovedností prokazuje stejný autorský kolektiv $\mathrm{v}$ navazujícím výzkumu až do poloviny druhého ročníku základní školy (Caravolas et al., 2019). V rozporu s mnohdy poměrně přesvědčivě šířenou představou, že české děti se naučí poměrně dobře číst $\mathrm{v}$ průběhu prvního ročníku základní školy, se tak ukazuje, že stabilita vývojové interakce a spolupráce klíčových předpokladů (dovedností) v procesu vývoje čtení vyžaduje $v$ celkovém náhledu relativně dlouhý čas, téměř dva roky. $\mathrm{V}$ případě českých dětí přibližně od poloviny posledního ročníku mateřské školy až do poloviny druhého ročníku základní školy. Pochopitelně $\mathrm{v}$ tomto kontextu vyvstává otázka potřebnosti a důležitosti cílené podpory těchto pro rozvoj počáteční gramotnosti klíčových dovedností $\mathrm{v}$ rámci předškolní př́pravy, případně i v čase vstupu do prvního ročníku základní školy (viz také Seidlová Málková, 2015).

Fonematické uvědomování je dovednost vědomé a pohotové manipulace se slovy na úrovni fonémů (Caravolas \& Volín, 2005). Znalost písmen chápeme nejen jako znalost názvů písmen abecedy (grafémů), ale také př́slušného zvuku, který se k písmenu pojí (Seidlová Málková, 2016). RAN neboli rychlé jmenování je schopnost pohotově si vybavovat názvy a výslovnost určitých 
symbolů užívaných v jazyce (např. písmen, číslic, ale i obrázků; Seidlová Málková, 201, s. 141-143). Dovednost rychlého jmenování si můžeme představit jako „mechanismus“ odpovědný za budování systému spojení vizuální podoby slova a tím, jak jej čteme (Seidlová Málková, 2015, s. 15).

Pro rozvoj čtení je podstatné, aby dítě rozumělo, že systém zvuků mateřského jazyka souvisí s písmeny a je jimi reprezentován. Fonematické uvědomování a znalost písmen se v průběhu vývoje vzájemně ovlivňují a postupně provazují, tak jak si dítě uvědomuje tzv. alfabetický princip (že každý zvuk mluvené řeči je možné zapsat písmenem, grafémem) a jak si vytváří stále přesnější soubor znalostí o korespondencích fonémů a grafémů svého mateřského jazyka.

Současné studie naznačují (i když se nepochybně jedná v odborném prostředí o stále diskutované téma), že fonematické uvědomování vývojově nevyžaduje pro svůj rozvoj znalost písmen abecedy ani to, aby se dítě začalo učit číst a psát (viz Hulme et al., 2005; Seidlová Málková \& Caravolas, 2016). V podstatě je fonematické uvědomování projevem postupného obohacování fonologických schopností dítěte ve smyslu narůstající integrace stále většího rozsahu a stále složitějších kognitivních operací - proto hovoříme o fonematickém uvědomování jako o metajazykové znalosti (Seidlová Málková, 2014). Vývoj fonematického uvědomování i rozvoj znalosti písmen je možné významným způsobem podpořit cílenými a strukturovanými výukovými nebo tréninkovými aktivitami (Seidlová Málková \& Caravolas, 2016; Seidlová Málková, 2015).

Výše uvedené klíčové dovednosti předškolního dítěte tvoří důležitý soubor kognitivních a jazykových předpokladů úspěšného čtenáře i pisatele a užívají se pro včasnou identifikaci rizik ve vývoji gramotnosti. Trénink fonematického uvědomování zlepšuje nejen fonematické uvědomování, ale do určité míry také čtenářské dovednosti (Bus \& Ijzendoorn, 1999), a jeho vývoj lze výrazně ovlivnit cílenými výukovými aktivitami (Callaghan \& Madelaine, 2012).

\section{TYPICKÉ FORMY REALIZACE INTERVENČNÍCH PROGRAMŮ PRO PODPORU ROZVOJE PREGRA- MOTNOSTNÍCH DOVEDNOSTÍ}

Porozumění důležitosti fonematického uvědomování a znalosti písmen pro rozvoj počátečních čtenářských dovedností vedlo v posledních letech $\mathrm{v}$ řadě evropských zemí $\mathrm{k}$ nárůstu zájmu o intervenční programy podporující jejich rozvoj. Tvůrci těchto programů i profesionálové ve školské praxi si uvědomují důležitost takových intervenčních zásahů zejména pro děti s rizikovými faktory z hlediska vývoje gramotnosti, zejména pro děti s oslabeným vývojem fonematického uvědomování. Řada intervenčních programů pro rozvoj fonematického uvědomování (nebo širšího souboru pregramotnostních dovedností) byla také konstruována a tes- 
tována primárně pro potřeby dětí $\mathrm{s}$ riziky ve vývoji gramotnosti (jako např. rodinné riziko dyslexie, poruchy řeči, vývojová dysfázie). $V$ současné době je tak v řadě evropských zemí (v Evropě zejména ve Velké Británii a v Holandsku) $\mathrm{k}$ dispozici uspokojivé množství výzkumně ověřených intervenčních programů, které mohou učitelé a profesionálové ve školské praxi, ale i rodiče dětí předškolního a raně školního věku, využívat.

Dvě nejčastější formy intervenčních programů pro rozvoj počátečního čtení v zahraničním kontextu jsou fonematické uvědomování a znalost písmen ve spojení $s$ fonematickým uvědomováním. Postupem času můžeme vidět trend směrem ke stále propracovanějšímu propojení fonematického uvědomování (jeho různých vývojových stupňů) se znalostí písmen (různých vývojově adekvátních projevů této dovednosti). $\mathrm{V}$ souvislosti $s$ výukovými či herními aktivitami $\mathrm{v}$ oblasti znalosti písmen bývá zdůrazňován termín „znalost tišš̌ného písma" (print knowledge; McGinty et al., 2011), tj. seznámení dítěte se zápisem textu. Nejde tedy jen o trénink rozpoznávání grafémů příslušné abecedy, ale může se jednat např́ḱlad i o společné čtení provázené zvýrazňováním prvních písmen ve slovech, psaní písmen abecedy, hledání určitých písmen (např. iniciály dítěte) v říkankách a rýmech, kdy děti písmena obtahují, atp. Intervenční programy se snaží svým herně zaměřeným prostředím co nejvíce zaujmout pozornost dítěte, at́ už obsahem (charakterem volených herních aktivit), nebo formou (cvičení typu tužka-papír či počítačem asistované aktivity, multimediální herní aplikace). V praxi také často dochází ke kombinování různých forem intervenčních aktivit: např. práce logopeda orientovaná na nápravy řeči provázaná $s$ tréninkem pregramotnostních dovedností v mateřské škole či příslušném poradenském zařízení (Byrne \& Fielding-Barnsley, 1993), spojení společného čtení dítěte $s$ rodičem $s$ dalšími konkrétními aktivitami pro podporu rozvoje pregramotnostních dovedností apod.

$\mathrm{V}$ následující části textu představujeme některé programy na podporu rozvoje pregramotnostních dovedností a shrnujeme výsledky studií, ve kterých byly uplatněny. Výběr těchto programů není rozhodně vyčerpávající. Stručnými popisy zvolených intervenčních programů chceme především demonstrovat pestrost forem realizace intervenčních programů pro podporu rozvoje pregramotnostních dovedností i šíri spektra cílových skupin, na které tyto programy cílí.

Program Sound Foundations (Byrne \& Fielding-Barnsley, 1991), hojně užívaný $\mathrm{v}$ anglicky mluvících zemích, se zaměruje na budování tzv. alfabetického principu, tedy korespondence hlásky a písmene a postupný rozvoj techniky elementárního čtení. Jde o systém vzájemně propojeného tréninku fonematického uvědomování a znalosti písmen a základních čtenářských dovedností. Celý program je dnes implementován 
jako ucelený systém podpory rozvoje pregramotnostních a raně gramotnostních dovedností dětí $\mathrm{v}$ prủběhu celého předškolního období, cílí na rodiče, pedagogy i vychovatele $\mathrm{v}$ předškolních zařizeních (www.soundfoundations. co.uk). Program je bohatě metodicky naplněn, obsahuje řadu výukových materiálů a pomůcek jako např. velké barevné plakáty, pracovní sešity, poslechová cvičení, sady kartiček s obrázky slov sestavenými s cílem demonstrovat určitý princip hláskové stavby slov (např. slova začínající nebo končící na stejnou hlásku). Program byl výzkumně ověřen (Byrne, Fielding-Barnsley \& Ashley, 2000) ve skupině 64 předškolních dětí, které pracovaly ve tř́idě s učitelem s modifikovanou verzí programu v menších skupinkách 4-6 dětí, přibližně půl hodiny týdně po dobu 12 týdnů. Autoři efekt tréninkového programu sledovali s odstupem šesti let v době, kdy sledované děti již docházely do pátého ročníku základní školy. Děti, které $\mathrm{v}$ předškolním věku podstoupily trénink fonematického uvědomování, vykazovaly $\mathrm{v}$ době odloženého měření výrazně lepší výsledky v testech čtení slov, nepravidelných slov i pseudoslov. Rozsah osvojení fonematického uvědomování $\mathrm{v}$ předškolním věku $\mathrm{v}$ rámci tréninkových aktivit určoval podle autorů studie variabilitu v následném vývoji gramotnostních dovedností. Děti, které si v rámci tréninkových aktivit vybudovaly dobré fonematické uvědomování, postupovaly v následných letech ve vývoji gramotnostních dovedností rychleji a lépe než děti, které nebyly trénovány nebo si v rámci tréninkových aktivit nedokázaly fonematické uvědomování vybudovat $\mathrm{v}$ dostatečném rozsahu.

Program Road to the Code: A Phonological Awareness Program for Youth Children (Blachman et al., 2000) je určený pro předškolní a raně školní děti s obtížemi, jedná se o jedenáctitýdenní program fonematických dovedností a znalosti písmen, koncipovaný do 44 lekcí v rozsahu 15-20 minut pro práci pedagoga v malé skupině dětí. Při experimentální studii k uvedení tohoto programu bylo sledováno sedm dětí s obtížemi v oblasti fonologického uvědomování v předškolních tř́idách mateřských škol. Děti předškolního věku s identifikovanými obtížemi v oblasti fonologických dovedností byly vyhledány $\mathrm{v}$ sedmi mateřských školách. Celkem se experimentální studie ve výsledku účastnilo šest dětí, které pracovaly s tímto programem v oblasti fonematického uvědomování, zvuků a písmen, čtení slov a počátečního konceptu čtení. Efektivita programu byla tímto výzkumem potvrzena, program zvyšuje dovednosti fonologického uvědomování, které mají tendenci přetrvávat i po ukončení tohoto tréninku. Recipienti programu nabyté vědomosti zobecňovali a používali je $\mathrm{v}$ dalších, nových situacích.

Segersová a Verhoeven (2004) ve své studii s dětmi s vývojovou dysfázií vytvořili počítačem asistovaný intervenční program pro předškolní děti, který prostřednictvím deseti různých počítačových her podporuje rozvoj fone- 
matického uvědomování. Cílem studie bylo především ověřit efektivitu počítačem asistované intervence pro rozvoj fonematického uvědomování, ale také testovat př́nosy modulované prezentace mluvené řeči (např́klad zpomalení tempa prezentace slov) $v$ průběhu intervence právě pro děti $s$ vývojovou dysfázií. Intervenční program byl uspořádán celkem do 14 lekcí, každá lekce byla uvozena opakováním dovedností osvojených $\mathrm{v}$ předcházejících lekcích programu s poskytnutím zpětné vazby o míre jejich osvojení. $\mathrm{V}$ případě, že chybovost dítěte $\mathrm{v}$ předchozí hře klesne pod $20 \%$, software adaptivně přepne na náročnější hru. Studie byla metodicky uspořádána do tzv. pretestové, intervenční a jedné posttestové fáze. Studie se účastnily tř́i dvanáctičlenné skupiny dětí s vývojovou dysfázií: dvě skupiny (experimentální) pracovaly s připraveným intervenčním programem a jedna skupina dětí (kontrolní) pracovala $\mathrm{v}$ průběhu studie $s$ počítačovou hrou zaměřenou na podporu rozvoje slovní zásoby. Program $s$ fonologickým uvědomováním byl implementován ve dvou formách, $\mathrm{v}$ jedné experimentální skupině s využitím audio opory s běžnou mluvenou řečí a ve druhé skupině $s$ počítačem upravenou prezentací řeči umožňující rozvolnění tempa prezentace slov, zdůraznění určité části slova apod. Všechny sledované skupiny dětí pracovaly s cílovým počítačovým programem po dobu pěti týdnů. Čtrnáct lekcí cílového programu bylo tedy distribuováno formou cca tř́i patnáctiminutových setkání týd- ně. Výsledky studie dokládají pozitivní př́nosy programu pro rozvoj fonologického uvědomování, ovšem jen ve formě s využitím běžné (nemodulované) řeči. Př́nos programu s audio oporami s běžnou mluvenou řečí byl také prokázán jako relativně stabilní v čase: 18 měsíců po ukončení intervence vykazovala tato experimentální skupina $s$ fonologickým programem stále výrazně vyšší efektivitu (na úrovni fonologického uvědomování) ve srovnání s dalšími dvěma sledovanými skupinami dětí.

Př́kladem, jak může intervenční program na poli pregramotnostních dovedností vypadat u dětí se specifickými vzdělávacími potřebami, může být program zvolený na Novém Zélandu pro děti s Downovým syndromem (van Bysterveldt, Gillon \& Foster-Cohen, 2010). Tvůrci tohoto programu uvádějí, že u dětí s Downovým syndromem i přes aplikaci různých motorických cvičení či provedené operativní chirurgické zákroky často přetrvávají obtíže $s$ mluvenou řečí, a v důsledku těchto obtíží pak čelí mnohým rizikům $\mathrm{v}$ oblasti rozvoje čtenářských dovedností. Doporučují proto systematickou vzdělávací podporu dítěte $\mathrm{v}$ oblasti rozvoje pregramotnostních dovedností, tj. fonematického uvědomování a znalosti písmen, a to po celé předškolní období. Pro 10 dětí ve věku 4-5 let navrhli intervenční péči sestavit ze tř́i částí: 1. domácí program implementovaný rodiči (před započetím absolvovali rodiče informační a tréninkový večer, kde byli poučeni o poukazování na písmena a společném čtení knih 
s dítětem, intervence probíhala $10 \mathrm{mi}$ nut čtyřikrát týdně po dobu 18 týdnů, tj. celkem 12 hodin); 2 . řečová terapie se specialistou; 3. výuka prostřednictvím počítačového programu (celkem 20 hodin v průběhu 18 týdnů) - děti docházely do intervenčního centra, kde se každé ráno $\mathrm{v}$ týdnu věnovalo postupně šest různých specialistů malým skupinkám o rozsahu maximálně šesti dětí po dobu dvacetiminutového sezení. Tento program autoři realizovali rozdělený do dvou šestitýdenních cyklů. Výzkumné šetření ukázalo významné př́inosy této péče po jejím skončení.

Sound Linkage (Hatcher, Duff \& Hulme, 2014) je tréninkový program uspořádaný do celkem 10 lekcí s cca 80 různými úlohami a aktivitami. Podobně jako dříve zmiňovaný Sound Foundations je i tento program zaměřený na trénink fonematického uvědomování a znalosti písmen s tím rozdílem, že trénink fonematického uvědomování předchází seznámení s písmeny a znalost písmen je budována důsledně ve spojení se znalostí hláskové struktury slov. V průběhu práce $s$ programem si děti postupně osvojují stále náročnější operace se slovy na úrovni různých lingvistických jednotek: dovednost rozpoznávání slov ve větách, rozpoznávání slabik ve slovech, identifikaci rýmů, elizi i transpozici hlásek ... až se dopracují $\mathrm{k}$ úlohám, ve kterých procvičují spojení hlásky a písmena, a postupně dokonce i elementární čtení (dekódování). Jednotlivé lekce jsou o rozsahu cca 30 minut. Tento program se těši ve Velké Británii značné oblibě, byl několikrát výzkumně evaluován a experimentálně implementován pro různé cílové skupiny. Nejčastěji se ale používá $\mathrm{v}$ běžných tř́dách školských zařízení jako nástroj včasné a systematické př́pravy pro typicky se vyvíjející děti na výuku čtení a psaní. V rámci výzkumného ověření programu se studie účastnily sedmileté děti se slabými čtenářskými výkony (tzv. poor readers). Pro potřeby intervenční studie byly děti rozděleny do čtyř skupin s odlišnými formami podpory výuky čtení: první skupina realizovala intervenci spojující trénink fonologického uvědomování s nácvikem čtení, druhá skupina obdržela čtenářrský trénink, třetí skupina fonologický trénink a čtvrtá, kontrolní skupina postupovala podle běžného výukového plánu. Implementace intervenčního programu probíhala po dobu 20 týdnů, v intenzitě cca dvou třicetiminutových lekcí týdně. $S$ programem pracovali pod supervizí výzkumného týmu vyškolení pedagogové. Děti pracovaly v průběhu implementace programu v malých skupinách, počtem variujících od dvou do devíti dètí v jedné skupině. Nejvýznamnější efektivita programu byla $\mathrm{v}$ závěrech studie sledována, ve srovnání se skupinou kontrolní, $\mathrm{v}$ př́ípadě experimentální skupiny, která realizovala fonologický trénink kombinovaný s podporou nácviku čtení.

$\mathrm{V}$ jiném programu (Tyler et al., 2014) podstoupily čtyřleté děti $\mathrm{v}$ integrovaných třídách (děti ohrožené nižším socioekonomickým postavením rodin a děti s obtížemi v jazyce či řeči, 
celkem čtyři děti) trénink fonematického uvědomování - skládání a rozkládání slov, propojování korespondencí grafémfoném - po dobu 10 týdnů s četností čtyři dny v týdnu v délce 20 minut na jedno sezení. Dětem poskytoval intervenci přímo pedagog $\mathrm{v}$ mateřské škole ve dvou skupinách (spolu s 10 a 14 dětmi ve skupinách). Cvičení obsahují úkoly typu skládání hlásek, rozkládání a sestavování slov, úlohy zaměřené na iniciály a rýmy, poznávání jednotlivých fonémů. Bezprostředně po tréninku byla tato studie ověřena jako prŕnosná $\mathrm{v}$ rámci integrovaných tříd pro takto staré děti s obtížemi, v př́ipadě běžně se vyvíjejících dětí nedosahovaly výsledky statistické významnosti.

GraphoGame je multimediální herní program původně sestavený pro výzkumné účely badatelským týmem z univerzity v Jyväskylä ve Finsku. Svým obsahem tato hra navázala na výsledky longitudinálního výzkumu předpokladů pro rozvoj počátečního čtení ve finštině (Lyytinen et al., 2006) a měla být používána především jako intervenční program pro děti s oslabeným fonematickým uvědomováním $\mathrm{v}$ předškolním věku. Jelikož je program konstruován tak, že cíleně a explicitně pomáhá vytvářet a procvičovat korespondence písmen a hlásek, začala se tato hra využívat i při práci $\mathrm{v}$ běžných předškolních třídách. Autoři této počítačem asistované hry (Richardson\& Lyytinen, 2014), a dnes především aplikace pro mobilní telefony a tablety, hledali způsob, jak umožnit dětem zábavnou formou fixovat a procvičovat jednotlivé grafémy finské abe- cedy a především spojení těchto grafémů $s$ príslušnou korespondující hláskou (fonémem). Orientace hry na základní dovednosti rozvíjející se gramotnosti (viz také první oddíl tohoto článku) učinila z GraphoGame velmi pružný a do jiných jazyků snadno adaptovatelný nástroj. Doposud byla tato hra přeložena a implementována ve 20 zemích světa (McTigue et al., 2020). Hra svým charakterem i herním prostředím připomíná jakoukoli jinou zábavnou počítačovou hru. Dostupné studie v mezinárodních odborných časopisech poskytují převážně pozitivní zprávy o prŕnosech GraphoGame ve školských zařízeních i v domácím prostředí ohrožených dětí. Např́íklad studie realizovaná tvůrci programu (Richardson \& Lyytinen, 2014) $s$ finskými dětmi předškolního věku před nástupem do prvního ročníku, kde se děti začínají učit číst a psát, jednoznačně mluví ve prospěch užití GraphoGame jako nástroje cílené př́ípravy na procesy učení se číst a psát. Mönkkönenová a kol. (2014) provedli studii ve finské mateřské škole. Děti zařazené do výzkumu byly rozděleny do tři skupin. První skupina pracovala s obvyklou verzí GraphoGame, druhá skupina pracovala s aplikací GraphoGame sestavenou pro podporu rozvoje početních dovedností a třetí skupina (kontrolní) nepodstoupila žádnou intervenci. Studie probíhala šest týdnů, děti strávily herní formou výuky celkem průměrně 3,5 hodiny. První skupina s čtenářskou aplikací měla významně lepší znalost písmen a pseudoslov oproti ostatním dvěma 
skupinám. Kyleová a kol. (2013) realizovali ve Velké Británii studii s anglicky mluvícími dětmi detekovanými jako slabí čtenáři ve věku 6-7 let. Po uplynutí 12 týdnů tréninkových aktivit v celkovém rozsahu 11 hodin intervenčních cvičení v aplikaci GraphoGame se děti zapojené do hry statisticky významně zlepšily v porovnání s kontrolní, neaktivní skupinou v testech čtení, hláskování a fonologických dovedností. Pozitivní př́nosy tohoto programu dokládá také aktuálně zveřejněná metalingvistická studie (McTigue et al., 2020), jejíž výsledky se opírají o přehled předchozích výzkumů efektivity GraphoGame v různých zemích, kde byl program dosud užíván a ověřován. Pozitivní přínosy GraphoGame jsou v závěrech této metaanalytické studie spojovány $s$ takovými formami implementace programu, kde se aktivně do organizace a realizace hry zapojovali dospělí v okolí dítěte (například ve formě podpůrné interakce $s$ dítětem $\mathrm{v}$ průběhu hry).

Nejčastější forma realizace podpory rozvoje pregramotnostních dovedností cílí na fonematické uvědomování. Vlivem pokračujícího výzkumu (napřr. Hatcher et al., 2014) jsou v posledních letech preferovány intervenční postupy kombinující trénink fonematického uvědomování s tréninkem znalosti písmen. Programy na podporu pregramotnostních dovedností se v zahraničí hojně užívají nejen u typicky se vyvíjejících předškolních dětí v běžných mateřských školách, ale cíleně také u dětí s vývojovými poruchami $\mathrm{v}$ oblasti gramot- nosti nebo u dětí s rizikovými faktory z hlediska vývoje gramotnostních dovedností. Implementace tréninkových programů vystavených na podpoře fonematického uvědomování (resp. fonematického uvědomování a znalosti písmen) prokazatelně pozitivně podporuje kvalitu a tempo rozvoje počátečního čtení (gramotnostních dovedností).

\section{OTÁZKA INTENZITY A DÉLKY IMPLEMENTACE INTERVENČNÍCH PROGRAMŮ}

Ukázaly jsme, že intervenční programy pro podporu pregramotnostních a raných gramotnostních dovedností mohou mít z hlediska četnosti či délky implementace, orientace na určitou cílovou skupinu i způsobů práce velmi variabilní formáty (Allen, 2011; Byrne et al., 2000; Suggate, 2016). Warren, Fey a Yoder (2007) např́klad sestavil za cílem jejich přehledného popisu (a pro následné hodnocení jejich efektivity) kategorizační systém inspirovaný zkušenostmi z praxe klinických logopedů u dětí s výraznými poruchami jazykového vývoje. Postupně formulovali důležitá kritéria pro popis formátů realizace intervenčních programů: forma, celková doba trvání intervence, frekvence, množství a kumulativní intenzita intervence.

Forma odkazuje ke kontextu aktivit a interakcí, vytvář́ kontinuum od „na dítě zaměřeného herního př́stu-

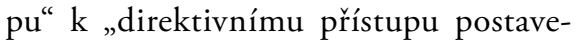
nému na drilu“. 
Celková doba trvání intervence je interval, po který intervence probíhá. To může být bud' předem stanovený časový rámec, či doba potřebná $\mathrm{k}$ nápravě. Podle Bakerové a McLeodové (2011), které pracují s dětmi s řečovými a sluchovými obtížemi, jsou obvykle tyto časové rámce v rozmezí od tří sezení do dvou let trvání. Nutno podotknout, že předurčený časový rámec však nezaručuje nápravu. Studie zabývající se délkou času potřebného $\mathrm{k}$ nápravě závažných obtíží se pohybují v rozmezí 3-46 měsíců, $s$ průměrem 12 měsíců pro fonologické intervence (Allen, 2013).

Další kritérium, množství, představuje počet sezení poskytovaných $\mathrm{v}$ určitém časovém rámci a délku každého sezení. Většina dětí s mírným až středně těžkým postižením řeči nebo jazyka má dvě sezení týdně v časovém rozsahu 20-30 minut (Mullen \& Schooling, 2010). U závažnějších obtíží může péče probíhat dvakrát až třikrát týdně po dobu 30-60 minut, avšak není prokázané, zda je intenzivnější intervence účinnější (Allen, 2011). Součástí je počet zaznamenaných učících epizod za sezení, to může být postup podle pravidel př́ručky (např. že dítěti je prezentován určitý počet tréninkových sad) či set aktivit, např. sluchové uvědomování, pojmové uvědomování a fonologické uvědomování v daném sezení.

Kumulativní intenzita intervence představuje výsledek množství, frekvence, a celkové doby trvání, o této oblasti toho doposud víme velmi málo.

Jaká je optimální intenzita intervenčního tréninku? Profesorka psychologie
M. M. Allenová (2011) zkoumala intenzitu intervenční péče u předškolních dětí $s$ poruchami vývoje řeči a jazykových schopností (speech sound disorders) orientované na fonologické uvědomování. Zabývala se otázkou, zda intervence, která probíhala intenzivněji (třikrát týdně), ale po kratší časový úsek (celkem osm týdnů), je účinnější než stejná intervence probíhající v delším časovém rozmezí, tj. jedenkrát týdně po dobu 24 týdnů. Ukázalo se, že intervence měla významně lepší př́ínos ve skupině, která obdržela intervenci intenzivnější, v rozsahu tří setkání týdně. Efekty programu u dětí, které pracovaly s programem jedenkrát týdně, byly podobné jako $\mathrm{v}$ případě aktivní kontrolní skupiny (ta aktivně pracovala s textem - děti četly, představovaly si písmena, realizovaly úkoly zaměřené na význam textu a slov atp.). K podobnému zjištění dospěli McGintyová et al. (2011) zkoumající otáz$\mathrm{ku}$ intenzity intervenčních programů, kde se děti seznamovaly $s$ tzv. tištěnou podobou písmen (print knowledge, viz výše v textu), s grafémy. Podle jejich názoru větší intenzita (2-4 sezení týdně) a rozsah péče (více různorodých způsobů výuky) jsou pro učení prospěšné, avšak pouze do určité míry (tedy je zde určitý strop).

Závěry $\mathrm{z}$ dosud realizovaných výzkumů tak naznačují, že z hlediska efektivity intervenčních programů můžeme hovořit o pozorovaných prrínosech bezprostředně či několik týdnů po skončení tréninkového programu, nebo s posuzováním střednědobých až dlouhodobých 
efektů několik měsíců až let po ukončení intervenčních aktivit.

Dlouhodobé př́nosy pročtenářsky orientovaných intervenčních programů sledoval Suggate (2016) v rámci své detailní metaanalytické studie. Suggate zhodnotil vliv působení různých intervenčních programů, které probíhaly ve většinové míře $s$ předškolními dětmi, u dětí v 1. a 2. tř́íách, přibližně rok po skončení těchto programů. $Z$ této studie vyplynulo, že pro-čtenářské intervence, které cílily na fonologické uvědomování, mají větší vliv než fonetické intervence. $Z$ hlediska dlouhodobých účinků určitého typu intervence a jejího přenosu na oblast porozumění čtení naznačuje současná analýza (tamtéž) důležitost cílení předškolních aktivit a mateřských škol na fonematické uvědomování, přičemž dekódovací dovednosti je dobré rozvíjet v 1. a 2. třídě, od 3. trrídy jsou optimální intervence zaměřené na porozumění čteného. To však nemusí platit $\mathrm{v}$ př́padě vytváření intervencí na míru individuálním potřebám dětí (Connor, Morrison \& Katch, 2004; Gersten et al., 2009). Klíčovým zjištěním uváděné metaanalytické studie je skutečnost, že silnějších účinků intervenčního působení dosahovaly jiné skupiny než typicky se vyvíjející čtenáři, tj. rizikové, s nižšími výkony či obtížemi - u těchto skupin můžeme pozorovat silnější dosažitelné dlouhodobé efekty. Tuto skutečnost potvrzují i další autoři (Elbro \& Petersen, 2004), kdy trénink fonematického uvědomování u dětí s dyslexií prokázal větší účinky než v neselektované skupině dětí. $\mathrm{V}$ jiné studii (Hindson et al, 2005) prokázal trénink fonematického uvědomování a znalosti písmen též vyšší efekty u rizikových dětí z dyslektických rodin (vyjma znalosti písmen). Doložitelné jsou dlouhodobé účinky tréninku fonematického uvědomování i s několikaletým posttestem, ty to vlivy se však časem prokazatelně výrazně snižují. I přesto je zřejmé, že s odkladem několika let jsou účinky u experimentálních skupin mírně vyšší, nemusí však nabývat hladiny statistické významnosti (Byrne et al., 2000).

Mnoho studií (viz např. metaanalytické studie Bus \& van Ijzendoorn, 1999, a Suggate, 2016) potvrzuje pozitivní přínos na úrovni (před)čtenářských dovedností dětí bezprostředně po ukončení pregramotnostního tréninkového programu. Suggate (2016) hovoří v souvislosti s raným čtenářstvím o několika kategoriích: a) normální čtenáři; b) rizikoví čtenáři (obvyklý výkon $\mathrm{v}$ testech čtení pod 50. percentilem nebo pocházející ze sociálně či ekonomicky znevýhodněného prostředí včetně dětí užívajících druhý jazyk);

c) čtenáři $s$ nízkým výkonem pod 25. percentilem; d) jedinci se čtenářskými obtížemi, kteří čtou pod 10. percentilem či mají diagnostikované čtenářskél IQ diskrepance jedné standardní odchylky. V rámci pregramotnostního tréninku mohou být cvičení volena podle vhodnosti pro danou kategorii čtenářů. Někteří autoři (Ehri et al., 2001) například zjistili, že podpora fonematického 
uvědomování byla prospěšnější pro počáteční rizikové čtenáře než pro čtenáře $s$ většími obtížemi. $\mathrm{V}$ některých studiích můžeme vidět tendenci přizpůsobit tréninkový program podpoře určitých oslabených dovedností konkrétní skupiny dětí. Dánské autotky Elbroová a Petersenová (2004) ve svém systému intervenčního programu pro děti s rizikem rozvoje dyslexie $\mathrm{v}$ předškolním věku zdůrazňují fonematické uvědomování (bez intervencí na úrovni fonologického uvědomování, tj. slabičné segmentace, rýmování, poslechových her ap.). Ve svém programu se zaměřily na jednotlivé hlásky řeči, nejprve byly prezentovány samohlásky, na což navázaly souhlásky. Př́slušné písmeno ke zvukové jednotce bylo pojmenováno a ukázáno. Jednotlivá písmena byla dětem zobrazena se záměrem pomoci rozlišit a zapamatovat si zvuky řeči. Př́nosy této metody vyšly statisticky významně větší z hlediska vlivu na pozdější čtení, než má samotný trénink fonematického uvědomování. Děti se seznamovaly $s$ písmeny a jejich korespondujícími hláskami, každá hláska byla součástí dětské ř́kanky a byla spojena s osobním jménem nějakého dítěte, děti byly povzbuzovány $\mathrm{k}$ hledání dalších souvisejících jmen, názvů a slov. Součástí byly též artikulační úlohy (doprovázené ilustrací), význam nové hlásky byl prezentován $\mathrm{v}$ páru se svým grafickým vyjádřením na tabuli, přičemž rýmy byly prezentovány s písmeny. Program vytvořil rámec pro intervenční práci se skupinou dětí s rizikem rozvoje dysle- xie; kontrolní skupinu ve výzkumu tvořily děti se stejnými rizikovými profily, které ale nepracovaly $s$ cílovým intervenčním programem, i děti typicky se vyvíjející. Intervenční aktivity lektorovali učitelé po dobu 17 týdnů v $30 \mathrm{minu}$ tových každodenních blocích. Výsledky studie prokázaly pozvolnou manifestaci pozitivních přínosů fonematické intervence: skupina dětí s rizikovými profily ve vývoji gramotnosti se svými výsledky ve čtenářských dovednostech pohybovala nejprve někde mezi netrénovanou rizikovou skupinou a typicky se vyvíjejícími dětmi (nebyla natolik pozadu oproti nerizikovým dětem). $\mathrm{V}$ dalších ročnících (ve 2. i v 7. třídě) bylo postupně zřetelné zlepšení oproti rizikové netrénované skupině. Ani rizikové děti, které podstoupily tréninkový program, však nedosahovaly výkonů srovnatelných s dětmi stejného věku z kontrolní skupiny bez rizika (Elbro \& Petersen, 2004).

Studie realizovaná v Dánsku (van Otterloo \& van der Leij, 2009) zkoumala u pěti- a šestiletých dětí s rodinným rizikem dyslexie př́nosy intervenčního programu Sounding Sounds and Jolly Letters připraveného pro užití v domácím prostředí dětí tak, aby podporu a vedení dětí mohli zajištovat jejich rodiče. I v tomto př́padě se jednalo o program postavený na systematické výuce a podpoře vývoje fonematického uvědomování a znalosti písmen. Aplikace programu byla časově naplánována přesně rok před započetím formální výuky čtení. Autoři tohoto intervenčního 
programu adaptovali pro užití rodiči intervenční program připravený původně pro práci ve třídách mateřských škol (Towards Initial Reading: Phonological Awareness; Borstrøm \& Petersen, 1996). Rodiče následně pracovali se svými dětmi v rozsahu 10 minut denně pět dní v týdnu po dobu celkem 14 týdnů. Výsledky studie umožňují srovnání př́nosů takto implementované intervence $s$ výkony vrstevníků, dětí s rizikem dyslexie, které se se svými rodiči doma nevěnovaly žádné intervenční práci. Autoři studie dokládají nejvýraznější přínosy intervenčního programu - bezprostředně po jeho ukončení - u znalosti písmen, výrazně menší u fonematického uvědomování. Přibližně rok po ukončení intervence, v době, kdy se už sledované děti učily číst a psát, bylo také u obou sledovaných skupin provedeno zjištění úrovně čtenářských a pisatelských dovedností. Děti z intervenční skupiny nevykazovaly oproti srovnávací skupině statisticky významně lepší výkony ani ve čtení, ani v psaní.

Délka a intenzita implementace intervenčních programů pro podporu rozvoje pregramotnostních dovedností jsou velmi důležitými, ale zřetelně ne snadno v praxi uchopitelnými faktory z hlediska orientace na úspěch intervencí. Základním krokem by vždy měla být snaha vyhledávat informace $\mathrm{z}$ již realizovaných intervenčních a evaluačních studií následovaná sérií pilotních, pečlivě monitorovaných a vyhodnocených formátů implementace.

\section{DosAVADNí ZKUŠENOSTI}

\section{$S$ IMPLEMENTACÍ INTERVENČNÍCH}

PROGRAMŮ PRO PODPORU

\section{ROZVOJE POČÁTEČNÍHO ČTENÍ}

\section{V ČESKÉM PROSTŘEDÍ}

Intervenční programy $\mathrm{v}$ oblasti předpokladů pro rozvoj počátečního čtení představují $\mathrm{v}$ českém prostředí stále spíše opomíjenou oblast (Seidlová Málková, 2016). Nejvíce praktických zkušeností se v České republice podařilo získat s intervenčním programem $\mathrm{Vkra-}$ jině slov a hlásek: Trénink jazykových schopnostípodle D. B. Elkonina. Program byl nejprve publikován a pro český jazyk adaptován ve své základní podobě jako trénink fonematického uvědomování (v kontextu Elkoninovy originální předlohy tzv. pregrafémová etapa; Mikulajová \& Dostálová, 2004). Díky aktivní práci autorského týmu doc. Mikulajové se $\mathrm{v}$ dalších letech postupně podařilo připravit $\mathrm{k}$ užívání $\mathrm{v}$ českém prostředí plnou verzi původního Elkoninova programu, která byla publikována pod názvem Trénink jazykových schopnosti podle D. B. Elkonina - predgrafémová a grafémová etapa (Mikulajová et al., 2016). Iniciativa uskupení elkonin. cz a cílená distribuce tohoto programu v systému dalšího vzdělávání pedagogických pracovníků na Pedagogické fakultě UK umožnila tento program nabídnout širokému spektru zájemců z řad pedagogů a speciálních pedagogů. I když systematický výzkum efektivity tohoto programu nebyl v České republice do- 
sud realizován, objevují se postupně dílčí poznatky a reflexe zkušeností s užíváním tohoto programu v praxi (Tokárová \& Mikulajová, 2012; Nováková Schöffelová, 2019; Nováková, Nováková Schöffelová \& Mikulajová, 2020).

Důležité doklady o př́nosech Elkoninova intervenčního programu v praxi pedagogicko-psychologického poradenství přinesla studie Tokárové (2015). Přestože se jedná o výzkum realizovaný na Slovensku, domníváme se, že jeho závěry jsou přenositelné i do praxe školské logopedie v České republice. Autorka na Slovensku sledovala střednědobé přínosy programu Trénink fonematického uvédomováni podle D. B. Elkoninapredgrafémová a grafémová etapa u dětí $s$ logopedickými diagnózami. Studie (tamtéž) operující s druhým, rozšířeným vydáním probíhala $s$ dětmi posledních ročníků mateřských škol (ve věku 5-6 let na začátku studie). Skupinu přibližně 50 typicky se vyvíjejících dětí a 50 dětí s diagnózou specificky narušeného vývoje řeči rozdělila autorka do čtyř sledovaných skupin: 1. trénink podle Elkoninovy metody se skupinou typicky se vyvíjejících dětí (70 lekcí à $45 \mathrm{~min}$ ), 2. děti s narušeným vývojem řeči zařazené do tréninku podle Elkonina (70 lekcí à $45 \mathrm{~min})$, 3. děti typicky se vyvíjející zařazené do programu stimulace pregramotnostních zručností podle kurikula MŠ (70 lekcí à $45 \mathrm{~min}$ ), 4. děti s narušeným vývojem řeči zařazené do logopedické intervence (70 lekcí à $45 \mathrm{~min}$ ). Vliv tréninku na fonematické uvědomování byl patrný jak u typicky se vyvíjejících dětí, tak u dětí s narušeným vývojem řeči, tj. vývojovou dysfázií, a to i s časovým odstupem - na konci 1. ročníku ZŠ. Děti s narušeným vývojem řeči zařazené do Elkoninova tréninku dosahovaly po tomto působení výkonů podobných výkonům běžně se vyvíjejících dětí.

Jedna z prvních výzkumných intervenčních studií pro podporu rozvoje pregramotnostních dovedností (fonematického uvědomování a znalosti písmen) $s$ českými dětmi byla realizována $\mathrm{v}$ rámci grantového projektu FHS UK v letech 2008 a 2009 týmem Seidlové Málkové a kolegů (Vztah izolace hlásek a znalosti pismen $v$ počátcích vývoje čtenárských dovedností, GA ČR 406/08/0338). Byly publikovány jen dílčí výsledky tohoto výzkumu, především na zahraničních konferencích (napr. Seidlová Málková \& Caravolas, 2010). Pilotní poznatky realizace intervenčního plánu pro podporu rozvoje fonematického uvědomování i znalosti písmen se stala východiskem pro navazující longitudinální studii v letech 2013-2015 (Seidlová Málková, 2015; Seidlová Málková \& Caravolas 2016). Tato studie se primárně zabývala řešením otázky vývojového vztahu fonematického uvědomování a znalosti písmen u předškolních dětí, nicméně v rámci její realizace bylo také možné hodnotit př́nosy $\mathrm{v}$ kontextu českého prostředí poměrně nezvykle navrženého formátu tréninku fonematického uvědomování a znalosti písmen $\mathrm{v}$ mateřských školách. Studie probíhala v celkem 12 mateřských školách, 
účastnilo se jí téměř 200 dětí ve věku 4,5-5 let (věk na začátku studie). V každé spolupracující mateřské škole byly děti zařazené do výzkumu rozděleny do trŕi sledovaných skupin: 1 skupina $s$ intervencí zaměřenou na fonematické uvědomování, 2. skupina $s$ intervencí zaměřenou na znalost písmen, 3. kontrolní skupina bez intervenčních aktivit. Oba intervenční plány zahrnovaly celkem 35 lekcí rozvržených do sedmi týdnů práce ve třídách. Intervenční aktivity $\mathrm{v}$ mateřských školách realizovaly podle připraveného metodického plánu proškolené třídní učitelky. Časová dotace jedné lekce byla 30-45 minut, lekce intervenčních programů probíhaly každý den v průběhu posledních dvou měsíců školního roku ve druhém ročníku mateřské školy. Oba intervenční programy byly sestavené $s$ konkrétním herním motivem, $v$ prrípadě tréninku fonematického uvědomování se jednalo o výlet do pohádkově laděné „Krajiny slov“, $\mathrm{v}$ př́padě písmenného tréninku šlo o výlety do „Písmenkového cirkusu“. Z hlediska obsahu byly oba programy sestavené jako série úkolů, cvičení a aktivit připravených pro práci pedagoga $\mathrm{v}$ běžných třídách mateřských škol s využitím připraveného metodického manuálu, obrazového materiálů a pracovních listů. Intervence zaměřená na fonematické uvědomování se skládala ze dvou částí a inspirovala se materiálem $\mathrm{z}$ jediného $\mathrm{v}$ době realizace dostupného uceleného tréninkového programu v českém jazyce, programu Vkrajiné slov a hlásek (Mikulajová \& Dostálová, 2004) a částečně také britským programem Sound Linkage (Hatcher et al., 2014). Pozornost byla zaměřována na slabičnou a hláskovou stavbu slov, zejména na identifikaci počáteční hlásky ve slově a na „vizualizaci“ hlásek. V průběhu programu se děti postupně prostřednictvím herně orientovaných cvičení seznámily s 24 hláskami. Program pro podporu rozvoje znalosti písmen zval děti v průběhu každého setkání na návštěvu písmenkového cirkusu, inspirovaného knihou Kamarádi z abecedy (Petrák \& Malý, 2012). Každý den se děti v písmenkovém cirkusu potkávají s písmenky, seznamují se s nimi nebo si fixují a procvičují jejich vizuální podobu, v průběhu jednotlivých lekcí se postupně seznámí téměř se všemi písmenky české abecedy. Přínosy uvedených intervenčních aktivit byly měřeny a vyhodnocovány bezprostředně po jejich ukončení a ještě znovu s odstupem přibližně osmi měsíců (v době, kdy sledované děti navštěvovaly poslední ročník mateřské školy před nástupem do ZŠ). Oba evaluované formáty tréninkových programů se prokázaly jako efektivní a prŕnosné z hlediska rozvoje cílových dovedností (fonematické uvědomování nebo znalost písmen). Oba implementované formáty intervence také prokázaly jistou míru stability přínosů pro cílové dovednosti v čase - i osm měsíců od ukončení tréninkových aktivit. Z hlediska rozvoje tzv. alfabetického principu (spojení hlásky a písmene) se ukázal jako výrazně efektivnější formát tréninku se znalostí písmen, kde zřejmě docházelo ke spontánní aktivizaci 
znalostí o korespondencích grafémů a hlásek. Trénink s písmeny byl proto z hlediska rozměru přínosů celkově robustnější (Seidlová Málková, 2015).

Výsledky longitudinální studie Seidlové Málkové (2015) inspirovaly pochopitelně k dalšímu zájmu o problematiku systematické podpory pregramotnostních dovedností a prověrování nových forem realizace podpory rozvoje pregramotnostních dovedností. Autorky tohoto článku připravily společně $\mathrm{v}$ letech 2016 a 2017 studii inspirovanou záměry dřive zmíněného herního programu GraphoGame (Šedinová \& Seidlová Málková, 2017). Pracovaly s dětmi ve druhém pololetí předškolního ročníku mateřské školy, těsně před nástupem do prvního ročníku základní školy. $\mathrm{V}$ rámci této pilotní studie prověřily prúnosy krátkodobého, ale intenzivního desetitýdenního tréninkového programu zaměřeného na osvojování alfabetického principu, tedy explicitní modelování principu vazby fonému a grafému. Celkem 69 dětí bylo zařazeno do jedné ze tří skupin skupiny $s$ předčtenářsky orientovaným tréninkem, skupiny s tréninkem zaměřeným na grafomotorické dovednosti a kontrolní skupiny stejně starých dětí bez tréninku. Náplní prověřované formy tréninkových aktivit byla intenzivní systematická forma prezentace herně orientovaných aktivit pro podporu rozvoje fonematického uvědomování a znalosti písmen. Děti v tréninkových skupinách se setkávaly $s$ frekvencí tř̌ikrát týdně po dobu cca 30 minut (celkem 29 lekcí) se svým běžným pedagogem $\mathrm{v}$ menších skupinkách. Pilotní výsledky výzkumu, které zachycují výsledky bezprostředně po ukončení tréninkových aktivit, ukazují na uspokojivou efektivitu tréninkového programu (středně silné hodnoty míry účinku u cílových dovedností).

Přehled poznatků z výzkumu přínosů cílené a strukturované podpory rozvoje fonematického uvědomování v českém (ale i slovenském) prostředí poskytuje důležité východisko pro další studium a systematický výzkum $\mathrm{v}$ této oblasti. Poznatky, které máme v českém prostředí dosud k dispozici, jasně ukazují, že systematická podpora rozvoje fonematického uvědomování provázaná s podporou rozvoje alfabetického principu je funkční a efektivní formou předškolní př́ípravy na výuku čtení a psaní. Prokazatelně může pozitivním způsobem ovlivnit plynulost a snížit náročnost procesu osvojování počátečního čtení a psaní. Potřeba dalš́iho výzkumu, zejména s dětmi s rizikovými faktory ve vývoji gramotnosti, je silná (viz např. alarmující výsledky výzkumu Kucharské, 2014, nebo Richterové, 2019). Strukturovaná podpora v oblasti rozvoje fonematického uvědomování a znalosti písmen je velmi př́nosná a organizačně také nejméně náročná v podobě integrované do vzdělávací činnosti běžných třrid mateřských škol (Seidlová Málková, 2015). Domníváme se, že dobře metodicky uchopená podpora rozvoje pregramotnostních dovedností, zejména fonematického uvědomování, je důležitou součástí práce pedagogů v mateřských školách. Právě pro tento účel jsme na základě našich dosavadních 
zkušeností a na základě znalostí této problematiky z odborné zahraniční literatury sestavily strukturovaný metodický materiál, který se může stát podkladem pro implementaci tréninkového programu do tříd běžných mateřských škol.

\section{NÁVRH METODICKÉHO PROGRAMU PODPORY ROZVOJE PREGRAMOT- NOSTNÍCH DOVEDNOSTÍ}

V návaznosti na dosavadní zkušenosti z výzkumu efektivity programů pro podporu rozvoje pregramotnostních dovedností a počátečního čtení v České republice jsme navrhly výukový program pro použití v běžných tř́ídách mateřských škol. Metodický materiál s názvem Vètuška a Slovánek v lese plném hlásek a pismen cílí na explicitní výuku tzv. alfabetického principu (spojení hlásky a písmene) a je sestavený jako ucelený program, série na sebe navazujících úloh pro intenzivní implementaci v průběhu cca dvou měsíců předškolního ročníku MŠ. Úlohy, které jsou součástí programu, rozvíjejí základní úroveň dovednosti fonematického uvědomování (zejména vydělení počáteční hlásky ve slově) a znalosti písmen (zejména znalost vysloveného názvu písmene). Cílem programu je především aktivizace základních předčtenářských dovedností pro podporu typicky se vyvíjejících dětí, proto součástí programu není výuka názvů písmen abecedy ani elementárního čtení. Program je koncipován pro přímou práci pedagogů $s$ dětmi ve tř́dách jako soubor metodických návodů, obrázků a pracovních listů pro práci ve formátu tužka-papír na podkladě ústní instrukce pedagoga. Naše dosavadní zkušenosti ukazují, že pro práci s tímto programem lépe vyhovují menší skupiny dětí (6-8), a to především $\mathrm{z}$ důvodu snazší kontroly individuální práce. $V$ př́padě zapojení asistenta pedagoga a dobré př́pravy vedoucího pedagoga by jistě mohl být program užíván i v rámci výchovně-vzdělávacích aktivit celé třídy MŠ.

Podle dostupných poznatků z výzkumu (Elbro \& Petersen, 2004; Tyler et al., 2014; McTigue et al., 2020) je program vždy jen nástrojem v rukou pedagoga, který musí zvažovat optimální formy implementace programu do své třídy $s$ doporučenou pravidelností tří setkání týdně po dobu 20-30 minut. Vzhledem ke krátkodobosti programu (cca 10 týdnů) věříme $\mathrm{v}$ jeho snadnou implementovatelnost do mateřských škol v období před zahájením povinné školní docházky (zejména ve druhé polovině školního roku, čemuž je i daný program uzpůsoben vzhledem k období velikonočních a květnových svátků, kdy se $\mathrm{v}$ těchto prrípadech počítá se setkáním dvakrát v týdnu).

Při vytváření našeho pročtenářsky orientovaného programu jsme pochopitelně studovaly dostupné materiály a metodické principy uplatňované v domácím i zahraničním výzkumu $s$ aplikačním potenciálem. Seznámily jsme se $s$ úspěšnými programy a studiemi realizovanými v praxi, přičemž nás nejvíce oslovil výše zmiňovaný program 
GraphoGame (myšlenka explicitního a strukturovaného budování alfabetického principu pro děti $\mathrm{z}$ běžných tříd MŠ včetně multimediálního charakteru programu; Lyytinen et al, 2006), a dále program Sound Linkage (v rámci něhož bylo potvrzeno, že pregramotnostní dovednosti, fonematické uvědomování a znalost písmen je třeba provazovat; Hatcher et al., 2014). První podoba programu, z níž předkládaný intervenční program vychází, byla vytvořena pro pilotní výzkumné ověření $\mathrm{v}$ mateřských školách (Šedinová \& Seidlová Málková, 2017) a následně modifikována tak, aby důsledně cílila jen na explicitní demonstraci a modelování tzv. alfabetického principu (souvislosti hlásky a písmene) a mohla vyhovovat velmi krátké a intenzivní formě implementace do běžných mateřských škol.

Program je tvořen čtyřmi na sebe navazujícími oddíly - úvodní oddíl s důrazem na vystavění herního kontextu, fonologický oddíl (dále strukturovaný do slabičné a hláskové části), písmenkový oddíl a oddíl s procvičováním a opakováním s důrazem na posílení alfabetického principu (propojení foném-grafém). Každý oddíl tvoří série lekcí pro práci v jedné výukové hodině. Každá lekce je tvořena strukturovanými popisy postupů a metod implementace tréninkového plánu a provází ji vhodný obrazový materiál (pracovní listy a obrázky). Jednotlivé lekce jsou sestaveny jako na sebe navazující, spojuje je jeden základní prríběh, který děti spolu s ústředními postavičkami progra- mu prožívají od začátku programu až po jeho ukončení.

Typické uspořádání lekcí v programu:

- od úvodních informací zaměřených na zorientování se v lekci po úkoly sloužící $\mathrm{k}$ zopakování předešlých aktivit a dovedností;

- seznámení se s novými znalostmi prostřednictvím společné či individuální práce (pracovní listy);

- závěrečné opakování a aktivity k posílení nově osvojených dovedností;

- doplňková cvičení (tj. nad rámec vymezené práce);

- aktivity určené $\mathrm{k}$ zopakování a uzavření probraného tématu.

Podrobný metodický manuál popisuje jednotlivé kroky a aktivity v př́slušné lekci, kurzívou je při popisu důležitých částí uvedena přímá řeč, kterou má v daných částech pedagog používat při popisu klíčových částí programu, aby byly co nejvíce sjednoceny edukativní interpretace.

Záměrem programu není seznámení dětí s principy čtení, ale príiblížit mluvenou řeč dítěti jako určitou strukturu, systém, a následně se naučit pracovat $s$ jeho jednotlivými částmi. V oblasti fonematického uvědomování cílí aktivity na identifikaci a vydělení počátečního fonému ve slově za opory vizualizačních pomůcek a herního kontextu. Druhá část navazuje seznámením s př́slušnými písmenky, grafickou podobou již procvičených fonémů. Ty děti přidělují $\mathrm{k}$ fonémům z fonematické části, a dochází $\mathrm{k}$ vzájemnému propojení těchto dovedností a jejich procvičení prostřednictvím 
zábavných her a aktivit různého charakteru vytvořených pro skupinovou, ale i individuální práci ve tř́ídě. Stejně jako u fonematické části, i část tréninku písmen je koncipována jako fantazijní a herně laděná aktivita. Písmena jsou dětem prezentována jako nástroj pro záznam zvuků mluvené řeči. Hry s písmenky nejen přispívají $\mathrm{k}$ samotnému rozpoznání správného tvaru písmene, ale součástí je též grafomotorický nácvik - děti si vyzkouší takové písmeno i napsat. Vzhledem k délce programu (program je krátkodobý, ale relativně intenzivní) byla záměrně volena písmena (a hlásky), které patří mezi typicky časně (a též spontánně) osvojované, a to: A, S, M, O, L, K, B, P. Zjednodušeně můžeme říci, že na vybrané sadě písmen a hlásek se snažíme dětem představit podstatu a princip fungování alfabetického principu.

Výukový plán se prolíná $\mathrm{v}$ poutavém kontextu s př́iběhem, který děti vtáhne do děje. Ústřední postavy - Větuška, která má ráda věty, a Slovánek, který má rád slova - jdou na návštěvu $\mathrm{k}$ dědečkovi a babičce, kteří pro ně mají dárek $\mathrm{k}$ ukončení předškolního vzdělávání. Postupně procházejí lesní krajinou, kde je lesní zvíŕátka a bytosti seznamují s hláskami a písmenky a pomáhají dětem uchopit mluvenou řeč jako určitou strukturu, systém. Postavy zvírátek a bytostí z lesa (žabák, luční kobylky, lesní žínky a skřítkové) děti seznamují s důležitými úkoly programu a mobilizují je k samostatné aktivitě $s$ nově získanými poznatky. Při práci s programem je pro podporu pred- stavy o plnění úkolů v lekcích využíván plakát ve tvaru stromu (větší obrázek) $s$ ústředními postavičkami a $s$ vyznačením počtu jednotlivých lekcí programu, který doporučujeme vytisknout na formát alespoň velikosti $\mathrm{A} 3$ do každé skupiny. Plakát slouží dětem jako vizualizační pomůcka, kde si děti mohou značit nejen každou absolvovanou lekci - projitý úsek - prostřednictvím vybarvení šištiček stromu (počet lekcí představuje počet těchto šištiček, posloupně uspořádaných), ale též jako prostor, kam si mohou zaznamenávat nebo zakreslovat nově získané informace či poznatky.

Jednotlivá cvičení jsou koncipovaná z vývojového hlediska, aby co nejvíce odpovídala předškolnímu období, od jednoduchých úkolů přes aktivity $s$ postupně se zvyšující náročností až po složitější formy cvičení na kumulativním principu již naučených dovedností. Aby byla upoutána pozornost dítěte, skupinová cvičení prolínají individuální aktivity, cvičení u stolečku jsou doplňována rozmanitými aktivitami mobilizujícími tvořivé, pohybové, grafomotorické, kreativní a hudební dovednosti. U samotných cvičení se prolínají různé typy aktivit - forma tužka-papír, aktivity s modelínou, kreslení, rýmy, písničky, činnosti vyžadující rytmickou práci, pozornostní aktivity atp.

Vzhledem $\mathrm{k}$ současným trendům v zavádění využívání moderních informačních a komunikačních technologií v edukativním př́stupu je součástí tištěné pracovní verze tužka-papír také ICT verze tohoto intervenčního tréninkového 
programu do tabletů a PC. Obě verze metodického materiálu - tištěná forma tužka-papír i elektronická forma do tabletů/PC - jsou určeny pro skupinovou práci pedagoga s menší skupinou dětí (6-8) a založeny na podpoře tzv. alfabetického principu. Je na pedagogovi, aby zvážil technické možnosti ve své tř́ídě a podle toho volil verzi programu. Př̀i práci s tablety je žádoucí, aby učitel i každé dítě ve třídě mohli pracovat s vlastním př́istrojem.

\section{ZÁVĚR}

Problematika systematické tréninkové či intervenční podpory rozvoje pregramotnostních dovedností $\mathrm{v}$ předškolním věku je důležitým a ve výzkumu potřebným tématem. V České republice disponujeme doposud limitovaným rozsahem zkušeností $\mathrm{z}$ výzkumu př́nosů a efektivity těchto intervenčních programů. To je zřejmě odrazem organizační i finanční náročnosti výzkumu $\mathrm{v}$ této oblasti, ale zcela jistě to také odráží malé množství dostupných metodických materiálů, které by se mohly stát pevnou a sdílenou oporou pedagogů a psychologů ve školské poradenské i speciálněpedagogické praxi. Realizace intervenční či tréninkové opory v oblasti rozvoje pregramotnostních dovedností $\mathrm{v}$ předškolním věku je přitom téma, které nepotřebuje obhajovat: výsledky dosud realizovaných výzkumných studií - v domácím i zahraničním prostředí - mluví jasně ve prospěch jejich zavádění. A to at už $\mathrm{v}$ príípadě cílové skupiny typicky se vyvíjejících dètí a aktivizace jejich předčtenářských dovedností, nebo (zejména) u skupin dětí s rizikovými faktory ve vývoji gramotnostních dovedností. Pokračující diskuse a uskutečnění dalšího výzkumu je ovšem potřeba v otázkách implementace těchto programů - forem, délky a intenzity provedení u různých cílových skupin. Specifickou výzvou pro realizaci intervenčních či tréninkových programů s podporou rozvoje fonematického uvědomování a znalosti písmen (pregramotnostních dovedností obecně) je využití počítačem asistovaných, elektronických nebo multimediálních formátů. V této oblasti jde $\mathrm{v}$ českém prostředí o stále nenaplněný prostor. Potřebu jeho zaplnění nepochybně umocňují i zkušenosti, které českému poradenskému systému a školství přinesla pandemie covid-19.

\section{Literatura}

Allen, G. (2011). Early intervention: The next steps, an independent report to Her Majesty's government by Graham Allen MP. The Stationery Office.

Allen, M. M. (2013). Intervention efficacy and intensity for children with speech sound disorder. Journal of Speech, Language, \& Hearing Research, 56(3):865-877.

Baker, E., \& McLeod, S. (2011). Evidence-based practice for children with speech sound disorders: Part 1 narrative review. Language, Speech, \& Hearing Services in Schools, 42(2):102-139. 
Blachman, B. A., Ball, E. W., Black, R., \& Tangel, D. M. (2000). Road to the code: A phonological awareness program for young children. Baltimore: Paul $\mathrm{H}$. Brookes.

Borstrøm, I., \& Petersen, D. K. (1996). På vej til den forste lasning. Fonologisk opmarksomhed [On the way to the first reading. Phonological awareness]. Copenhagen: Alinea.

Bus, A. G., \& Van Ijzendoorn, M. H. (1999). Phonological awareness and early reading: A meta-analysis of experimental training studies. Journal of Educational Psychology, 91(3), 403-414.

Byrne, B., \& Fielding-Barnsley, R. (1991). Evaluation of a program to teach phonemic awareness to young children. Journal of Educational Psychology, 83(4), 451-455.

Byrne, B., \& Fielding-Barnsley, R. (1993). Evaluation of a program to teach phonemic awareness to young children: A 1-year follow-up. Journal of Educational Psychology, 85(1), 104-111.

Byrne, B., Fielding-Barnsley, R., \& Ashley, L. (2000). Effects of preschool phoneme identity training after six years: Outcome level distinguished from rate of response. Journal of Educational Psychology, 92(4), 659-667.

Callaghan, G., \& Madelaine, A. (2012). Levelling the playing field for kindergarten entry: Research implications for preschool early literacy instruction. Australasian Journal of Early Childhood, 37(1), 13-23.

Caravolas, M., Lervåg, A., Mousikou, P., Efrim, C., Litavský, M., Onochie-Quintanilla, E., ... \& Seidlová-Málková, G. (2012). Common patterns of prediction of literacy development in different alphabetic orthographies. Psychological Science, 23(6), 678-686.

Caravolas, M., Lervåg, A., Defior, S., Seidlová Málková, G., \& Hulme, C. (2013). Different patterns, but equivalent predictors, of growth in reading in consistent and inconsistent orthographies. Psychological Science, 24(8), 1398-1407.

Caravolas, M., Lervåg, A., Mikulajová, M., Defior, S., Seidlová-Málková, G., \& Hulme, C. (2019). A cross-linguistic, longitudinal study of the foundations of decoding and reading comprehension ability. Scientific Studies of Reading, 23(5), 386-402.

Caravolas, M., \& Volín, J. (2005). Baterie diagnostických testì gramotnostnich dovedností pro žáky 2. až 5. ročníku Ž̌: príručka. Praha: Institut pedagogicko-psychologického poradenství ČR.

Connor, C. M., Morrison, F. J., \& Katch, L. E. (2004). Beyond the reading wars: Exploring the effect of child-instruction interactions on growth in early reading. Scientific Studies of Reading, 8(4), 305-336.

Ehri, L. C., Nunes, S. R., Stahl, S. A., \& Willows, D. M. (2001). Systematic phonics instruction helps students learn to read: Evidence from the National Reading Panel's meta-analysis. Review of Educational Research, 71(3), 393-447.

Elbaum, B., Vaughn, S., Tejero Hughes, M., \& Watson Moody, S. (2000). How effective are one-to-one tutoring programs in reading for elementary students at risk for reading failure? A meta-analysis of the intervention research. Journal of Educational Psychology, 92(4), 605-619. 
Elbro, C., \& Petersen, D. K. (2004). Long-term effects of phoneme awareness and letter sound training: An intervention study with children at risk for dyslexia. Journal of Educational Psychology, 96(4), 660-670.

Gersten, R., Compton, D., Connor, C. M., Dimino, J., Santoro, L., Linan-Thompson, S., \& Tilly, W. D. (2009). Assisting students struggling with reading: Response to intervention and multilevel intervention in the primary grades. A practice guide. NCEE 2009-4045. Washington, DC: National Center for Education Evaluation and Regional Assistance, Institute of Education Sciences, U.S. Department of Education. Dostupné z http://ies.ed.gov/ncee/wwc/publications/ practiceguides/.

Hatcher, P. J., Duff, F. J., \& Hulme, C. (2014). Sound Linkage: An integrated programme for overcoming reading difficulties. John Wiley \& Sons.

Hindson, B., Byrne, B., Fielding-Barnsley, R., Newman, C., Hine, D. W., \& Shankweiler, D. (2005). Assessment and early instruction of preschool children at risk for reading disability. Journal of Educational Psychology, 97(4), 687-704.

Hulme, C., Caravolas, M., Málková, G., \& Brigstocke, S. (2005). Phoneme isolation ability is not simply a consequence of letter-sound knowledge. Cognition, 97(1), 1-11.

Kirby, J. R., Georgiou, G. K., Martinussen, R., \& Parrila, R. (2010). Naming speed and reading: From prediction to instruction. Reading Research Quarterly, 45(3), 341-362.

Kyle, F., Kujala, J., Richardson, U., Lyytinen, H., \& Goswami, U. (2013). Assessing the effectiveness of two theoretically motivated computer-assisted reading interventions in the United Kingdom: GG Rime and GG Phoneme. Reading Research Quarterly, 48(1),61-76.

Kucharská, A. (2014). Riziko dyslexie. Pregramotnostni dovednosti a rozvoj gramotnosti v rizikových skupinách. Praha: Pedagogická fakulta UK.

Lyytinen, H., Erskine, J., Tolvanen, A., Torppa, M., Poikkeus, A. M., \& Lyytinen, P. (2006). Trajectories of reading development: A follow-up from birth to school age of children with and without risk for dyslexia. Merrill-Palmer Quarterly, 52(3), 514-546.

Markussen-Brown, J., Juhl, C. B., Piasta, S. B., Bleses, D., Højen, A., \& Justice, L. M. (2017). The effects of language-and literacy-focused professional development on early educators and children: A best-evidence meta-analysis. Early Childhood Research Quarterly, 38, 97-115.

McGinty, A. S., Breit-Smith, A., Fan, X., Justice, L. M., \& Kaderavek, J. N. (2011). Does intensity matter? Preschoolers' print knowledge development within a classroom-based intervention. Early Childhood Research Quarterly, 26(3), 255-267.

McTigue, E. M., Solheim, O. J., Zimmer, W. K., \& Uppstad, P. H. (2020). Critically reviewing GraphoGame Across the world: Recommendations and cautions for research and implementation of computer-assisted instruction for word-reading acquisition. Reading Research Quarterly, 55(1), 45-73.

Mikulajová, M., Nováková Schöffelová, M., Tokárová, O., \& Dostálová, A. (2016). Trénink jazykových schopností podle D. B. Elkonina. Predgrafémová a grafémová etapa. Praha: Centrum ROZUM. 
Mikulajová, M., \& Dostálová, A. (2004). V krajině hlásek a slov. Trénink jazykových schopností podle D. B. Elkonina. Bratislava: Dialóg.

Moll, K., Ramus, F., Bartling, J., Bruder, J., Kunze, S., Neuhoff, N., ... \& Tóth, D. (2014). Cognitive mechanisms underlying reading and spelling development in five European orthographies. Learning \& Instruction, 29, 65-77.

Mönkkönen, A., Bach, S., Brem, S., Erskine, J., Kujala, J., Willems, G., \& Richardson, U. (2014). Technology-enhanced training of basic decoding skills in preschool age children. $\mathrm{V}$ př́ípravě.

Mullen, R., \& Schooling, T. (2010). The National Outcomes Measurement System for pediatric speech-language pathology. Language, Speech, and Hearing Services in Schools, 41(1), 44-60.

Nováková, I., Nováková Schöffelová, M., Mikulajová, M. (2020). Když dítě vidí, co má slyšet. Trénink jazykových schopností dle D. B. Elkonina u dètí se sluchovým postižením. Praha: Pedagogická fakulta UK.

Nováková Schöffelová, M. (2019). Příprava dětí s dysfázií na čtení a psaní. Listy klinické logopedie, 3(1), 18-24.

Petrák, F., \& Malý, R. (2012). Kamarádi z abecedy. Host: Praha.

Richardson, U., \& Lyytinen, H. (2014). The GraphoGame method: The theoretical and methodological background of the technology-enhanced learning environment for learning to read. Human Technology, 10(1), 39-60.

Richterová, E. (2019). Počátečni vývoj čtenářských dovedností u dètí s vývojovou dysfázii. (Dizertační práce). Pedagogická fakulta UK.

Segers, E., \& Verhoeven, L. (2004). Computer-supported phonological awareness intervention for kindergarten children with specific language impairment. Language, Speech, \& Hearing Services in Schools, 35(3), 229-239.

Seidlová Málková, G., \& Caravolas, M. (2010). Phoneme training and its impact on letter learning. Seventeenth Annual Meeting Society for the Scientific Study of Reading, Berlin, 7.-10. 7.

Seidlová Málková, G. (2014). Vývoj fonologických schopností. In F. Smolík \& G. Seidlová Málková, Vývoj jazykových schopností v prèéškolnim věku. Praha: Grada.

Seidlová Málková, G. (2015). Vývojový vztah fonematického povédomi a znalosti pismen. Praha: Togga.

Seidlová Málková, G. (2016). Intervence v oblasti vývoje raných gramotnostních dovedností - přehled poznatků. E-Psychologie, 10(4), 65-75.

Seidlová Málková, G., \& Caravolas, M. (2016). The development of phoneme awareness and letter-sound knowledge: A training study of Czech preschool children. In M.-F. Morin, D. Alamargot \& C. Gonçalves (Eds.), Perspectives actuelles sur l'apprentissage de la lecture et de l'écriture (s. 31-56) [Contributions about learning to read and write]. Éditions de l'Université de Sherbrooke. 
Suggate, S. P. (2016). A meta-analysis of the long-term effects of phonemic awareness, phonics, fluency, and reading comprehension interventions. Journal of Learning Disabilities, 49(1), 77-96.

Šedinová, P., \& Seidlová Málková, G. (2017). Studie př́nosů intervenčního programu pro systematickou podporu rozvoje pročtenářských dovedností v předškolním věku. Gramotnost, pregramotnost a vzdèlávání, 1(2), 43-64.

Tokárová, O. (2015). Elkoninova metoda ranej gramotnosti a jej efektivita. (Dizertační práce). Pedagogická fakulta Univerzity Komenského v Bratislavě.

Tokárová, O., \& Mikulajová, M. (2012). Čítanie podl’a El'konina - charakteristika prístupu a opis metódy. Pedagogika, 62(1-2), 34-44.

Troia, G. A. (1999). Phonological awareness intervention research: A critical review of the experimental methodology. Reading Research Quarterly, 34(1), 28-52.

Tyler, A. A., Osterhouse, H., Wickham, K., Mcnutt, R., \& Shao, Y. (2014). Effects of explicit teacher-implemented phoneme awareness instruction in 4-year-olds. Clinical Linguistics \& Phonetics, 28(7-8), 493-507.

van Bysterveldt, A. K., Gillon, G., \& Foster-Cohen, S. (2010). Integrated speech and phonological awareness intervention for pre-school children with Down syndrome. International Journal of Language \& Communication Disorders, 45(3), 320-335.

van Otterloo, S. G., \& van der Leij, A. (2009). Dutch home-based pre-reading intervention with children at familial risk of dyslexia. Annals of Dyslexia, 59(2), 169-195.

Verhoeven, L., \& Van Leeuwe, J. (2008). Prediction of the development of reading comprehension: A longitudinal study. Applied Cognitive Psychology, 22(3), 407-423.

Warren, S. F., Fey, M. E., \& Yoder, P. J. (2007). Differential treatment intensity research: A missing link to creating optimally effective communication interventions. Mental Retardation \& Developmental Disabilities Research Reviews, 13(1), 70-77.

Mgr. et Mgr. Petra Šedinová

Univerzita Karlova, Pedagogická fakulta, Katedra psychologie;

e-mail: sedinova.p@gmail.com

doc. PhDr. Gabriela Seidlová Málková, Ph.D.

Univerzita Karlova, Fakulta humanitnich studii, Katedra psychologie a vèd o životè;

e-mail: gabriela.malkova@fhs.cuni.cz 


\section{ŠEDINOVÁ, P., SEIDLOVÁ MÁLKOVÁ, G. Specific Issues of Imple- mentation of Intervention Programmes to Support the Development of Pre-literacy Skills}

This study summarises research findings on intervention programmes (phoneme awareness and knowledge of letters) in preschool children and descriptions of the various forms of the realisation and implementation of these programmes. We present a conceptual and theoretical basis for the construction of developing literacy-oriented programmes and we demonstrate the variability with which these programmes are designed for use in practice and implemented for use in their target groups. Special attention is paid to the issues of implementation as they provide valuable support for possible evaluation in the context of pedagogical-psychological and special pedagogical practice. Separately, we present an overview of findings from international research and research in the Czech and Slovak Republics. In relation to analyses of recent findings and research experience from the Czech Republic, we also present new emerging methodological material for practitioners working in kindergartens.

Keywords: alphabetic principle, systematic education, intervention, phoneme awareness, letter knowledge, preschool age. 